\title{
Response to letter: More fat, less migration: breast density as a predictor of sentinel lymph node non-visualization in breast cancer
}

Youssef Chahid", Hein J. Verberne and Jan Booij

\section{To the Editor,}

We would like to thank Quak and colleagues for their interest in our recent publication where we found that age $\geq 70$ years, body mass index $(\mathrm{BMI}) \geq 30 \mathrm{~kg} / \mathrm{m}^{2}$ and nonpalpable tumors were independent risk factors for sentinel lymph node (SLN) nonvisualization during preoperative lymphoscintigraphy [1].

We read with great interest the findings of Quak et al. [2] that age and BMI are significantly associated with breast density. Patients with high fat content in breast tissue (i.e., low density) were, based on univariate analysis, significantly more at risk of SLN nonvisualization compared to patients with less fatty breast densities. Based on the combined findings of our study and that of Quak et al., it seems that SLN nonvisualization is driven in part by BMI and thereby lower breast density (more fatty breast tissue). Unfortunately, due to the lack of a multivariable analysis, we cannot properly assess the possible influence of breast density in relation to other risk factors (i.e., age and BMI) for SLN nonvisualization.
Nevertheless, based on the findings mentioned above, we do agree that breast density should be further investigated as a risk factor for SLN nonvisualization to optimize the lymphoscintigraphy protocol.

Yours sincerely,

Youssef Chahid, Hein Verberne, Jan Booij.

Received: 13 October 2021 Accepted: 15 October 2021

Published online: 29 October 2021

\section{References}

1. Chahid Y, Qiu X, van de Garde EMW, Verberne HJ, Booij J. Risk factors for nonvisualization of the sentinel lymph node on lymphoscintigraphy in breast cancer patients. EJNMMI Res. 2021;11(1):54.

2. Quak E, Braux G, Weyts K, Lasnon C. More fat, less migration: breast density as a predictor of sentinel lymph node non-visualization in breast cancer. EJNMMI Res (in press).

\section{Publisher's Note}

Springer Nature remains neutral with regard to jurisdictional claims in published maps and institutional affiliations.

${ }^{*}$ Correspondence: y.chahid@amsterdamumc.n

Amsterdam UMC Locatie AMC, Amsterdam, Noord-Holland, The

Netherlands original author(s) and the source, provide a link to the Creative Commons licence, and indicate if changes were made. The images or other third party material in this article are included in the article's Creative Commons licence, unless indicated otherwise in a credit line to the material. If material is not included in the article's Creative Commons licence and your intended use is not permitted by statutory regulation or exceeds the permitted use, you will need to obtain permission directly from the copyright holder. To view a copy of this licence, visit http://creativecommons.org/licenses/by/4.0/. 